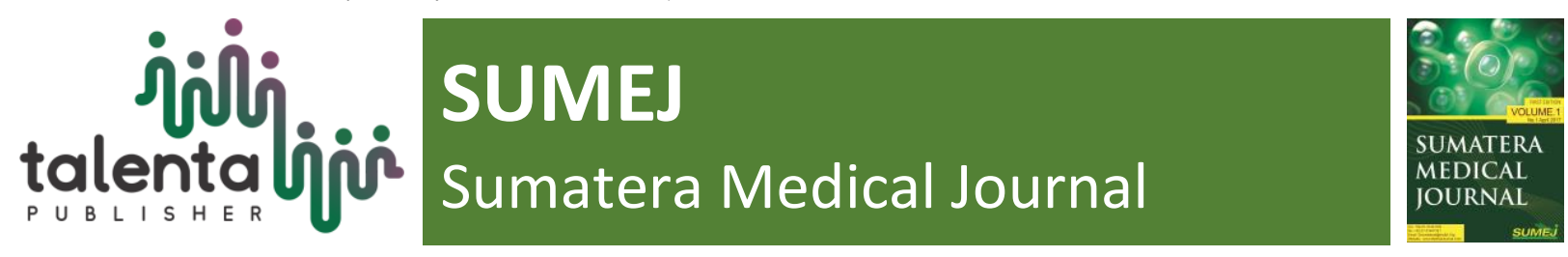

\title{
The Association between the Extend of Burn Injuries with Albumin Level on Burn Injury patients
}

\author{
Adetya Indah Sari ${ }^{*}$, Desiree Anggia Paramita \\ ${ }^{1}$ Faculty of Medicine, Universitas Sumatera Utara, Medan, North Sumatera, Indonesia \\ ${ }^{2}$ Department of Surgery, Faculty of Medicine, Universitas Sumatera Utara, Medan, North Sumatera, \\ Indonesia
}

\begin{abstract}
Burn injuries is a damaged or loss of skin caused by a contact with either high temperature sources or very low temperature sources. Burn injuries is classified according to its etiology, depth and extend of the wound. The extend of the burn can be determined by calculating TBSA (Total Body Surface Area). Wider TBSA will cause lower serum albumin levels due to a higher percentage increase. The purpose of this study was to determine the association between the extend of burn injuries with albumin levels on burn injury patients at Haji Adam Malik General Hospital Medan in 2017-2018. This research uses observational research with cross-sectional research design, using secondary data obtained from medical records at Haji Adam Malik General Hospital Medan in 2017-2018. The research sample was selected by using the total sampling method from all medical record data that met the research criteria. In this study, significant results were obtained with a value of $p=0.006$ ( $p<0.05$ ) between the extend of burn injuries and albumin levels in burn injury patients at Haji Adam Malik General Hospital Medan in 2017-2018.

Keyword: Burn injury, Albumin, TBSA, RSUP Haji Adam Malik, Medan
\end{abstract}

\section{Introduction}

Burn injuries is a damaged or loss of skin caused by a contact with either high temperature sources (such as fire, hot water, chemicals, electricity, and radiation) or very low temperature sources [1]. Combustion is a severe trauma with high morbidity and mortality rates. From the statistics, combustion is a major issue among all wounds as it poses 3 problems: ignorance, poorness, and a disease with many complications. It is also said that combustion is one of the severe wounds among all types of wound, and is a major global population health crisis as well as the fourth most common type of wound worldwide after traffic accidents, falls, and interpersonal violence [2].

In 2018, World Health Organization [3] estimated that there were 180.000 people who died every year globally due to combustion. Most of them happened in low and moderate income country. In Indonesia, the prevalence of combustion in 2013 was $0,7 \%$ which decreased about $1,5 \%$ compared to the prevalence in 2008 (2,2\%). The highest prevalence was in Papua, about

\footnotetext{
*Corresponding author at: Faculty of Medicine, Universitas Sumatera Utara, Medan, Indonesia

E-mail address: adetya.indahsari98@gmail.com
} 
$2,0 \%$ while the prevalence in East Kalimantan remained the lowest $(0.0 \%)$. The prevalence in North Sumatra was the same as those in West Java, Maluku and North Maluku, accounting for $0,9 \%$ [4].

Burn injuries is classified according to its etiology, depth and extend of the wound. The more extended the trauma on the body surface is, the more severe the condition and the worse the prognosis will be. Heat doesn't only damage the skin locally but also poses many common effects on the body. These changes are characteristic of burns and are not commonly found on other types of wound. There is usually an increase in capillary permeability because of the damage and heat effect. This causes plasma to leak to interstitial space. The increases in capillary permeability and plasma leakage occur up to 48 hours and are maximized in the first 8 hours. After 48 hours, capilarry permeability returns to normal or has thrombosis making it no more part of circulation. Loss of plasma is the cause of hypovolemic shock in burn injuries. The amount of fluid loss depends on how extended the burn was. Burn injuries on body surface is usually calculated using Wallace rules of nine for adults. For adults and children, table for Lund and Browder is used. For each adult who has a burn injury of more than 15\% and 10\% for each child will fall to hypovolemic shock unless a proper resuscitation is carried out. In a burn injury covering of 50\% of the body surface area, there is a possibility of maximed loss of fluid which will remain the same even when the burn covers more than $50 \%$ of body surface area [5].

Burn injuries causes loss of important proteins and acute inflammation which will affect the plasma protein synthesis in the liver. The more extended the TBSA (total body surface area), the lower the serum albumin level will be due to higher burning percentage. The burns will cause higher loss of protein and higher inflammation response with lower plasma protein synthesis [6].

Hypoalbunemia often occurs in critically ill patient, particularly in burn injury patients. Even when a burn covers less than $10 \%$ of the body surface area, changes in metabolism occurs. Burn injuries will result in hypermetabolic and hypercatabolic responds, depending on how deep and extended the burns are. A burn injury for more than $20 \%$ of body surface area will cause extracellular fluid loss, which in turn will trigger shock by increasing the blood vessel permeability and decreasing the plasma albumin level from the wound exudate. Hypoalbunemia also causes disorder in healing process, and increased sepsis susceptibility [7].

From the introduction explained above, the author is interested in doing a research about the association between the extend of burn injuries and albumin level on burn injury patients at Haji Adam Malik general hospital 2017-2018.

\section{Method}

This research uses analytical study to find the association among variables utilizing crosssectional approach to observe and measure the variables at a certain time. The data used in this research were collected from medical records at Haji Adam Malik general hospital as secondary data from August to October. 
The samples were all burn injuries patients in Haji Adam Malik general hospital from 2017 to 2018 and possessed some characteristics fulfilling the following inclusion criteria: burn injury patient at Haji Adam Malik general hospital from 2017 to 2018, older than 19 years old, recorded data of albumin level and the extend of the burn.

Univariate analysis was used in this research to find the frequency distribution and the percentages of the variables as the respondents' characteristics, including the dependent and independent variables. A bivariate analaysis was also carried out to find an asscociation between the dependent and independent variables. This analysis was held utilizing Fisher's Exact Test, in which the p-value was obtained and the significant level used in this research was 0.05. After that, the data were presented in the table and described.

This research has passed the ethical clearance No. 173/ TGL/KEPK FK USU-RSUP HAM/2019 from the Ethical Comission of Medical Faculty of Universitas Sumatera Utara/Haji Adam Malik general hospital Medan. The data were proccessed with IBM SPSS v. 21.0 for Windows and Compusyn.

\section{Result and Discussion}

The characteristics of the subjects used in this research could be grouped based on gender, age, extend of the burn and albumin level. This research gathered 32 burn injury patients as samples. These samples are burn injury patients who qualified for the inclusion criteria. From the data collected from medical records at Haji Adam Malik general hospital from 1 January 2017 to 31 December 2018, a total of 32 people were obtained as research subjects.

Table 1 Patients' Characteristics Based on Gender and Age

\begin{tabular}{clcc}
\hline No & Variable & Frequency & Percentage(\%) \\
\hline $\mathbf{1}$ & Age (years) & & \\
\hline & $21-40$ & 23 & 71.9 \\
& $41-60$ & 8 & 25.0 \\
& $>61$ & 1 & 3.1 \\
\hline $\mathbf{2}$ & Gender & & \\
\hline & Female & 8 & 25,5 \\
& Male & 24 & 75,0 \\
\hline & Total & $\mathbf{3 2}$ & $\mathbf{1 0 0 . 0}$
\end{tabular}

Based on table 1, burn injury patients were predominated by male patients, 24 patients were males $(75.0 \%)$, and 8 were females $(25.0 \%)$. These results are consistent with 
Febrianto [8] who did a research on 58 samples and found 44 (75.9\%) of them were males and $14(24.1 \%)$ were females. Awan et al.,[9] in their research stated that the number of burn cases in males was higher than that of female as males did more activities either indoor or outdoor.

Based on table 4.1, patients of burn injuries were predominated by the age of 20-40 years old, as many as 23 patients (71.9\%), whereas 8 patients (25.0\%) were 41-60 years old and only $1(3.1 \%)$ was $>61$ years old.

Table 2 Patients's Characteristics Based on Extend of Combustion Wound

\begin{tabular}{lcc}
\hline Extend of Burn & Frequency (n) & Percentage (\%) \\
\hline$>25 \%$ & 19 & 59.4 \\
$<25 \%$ & 13 & 40.6 \\
\hline Total & $\mathbf{3 2}$ & $\mathbf{1 0 0}$
\end{tabular}

Based on table 2, from the frequency distribution of burn injury patients at Haji Adam Malik general hospital, patients with $<25 \%$ wounded area were as many as 13 patients (40.6\%) while 19 patients $(59.4 \%)$ had $>25 \%$ wounded area.

Table 3 Patients's Characteristics Based on Albumin Level

\begin{tabular}{lcc}
\hline Albumin Level & Frequency (n) & Percentage (\%) \\
\hline Hypoalbumin & 27 & 84.4 \\
Normal & 5 & 15.6 \\
\hline Total & $\mathbf{3 2}$ & $\mathbf{1 0 0}$
\end{tabular}

Based on table 4.3, it could be seen that the distributed frequency for albumin level on patients with burn injuries at Haji Adam Malik general hospital were predominated with hypoalbumin. There were 27 patients $(84.4 \%)$ with hypoalbumin and 5 patients $(15.6 \%)$ with normal albumin level. The albumin level in this research tended to decrease because of the changes in the plasma of burn injury patients resulting in decreasing serum albumin concentration.

The objective of this research is to find whether there is an association between the extend of the burn and albumin level. The data are categorical so a chi-square test was utlized.

Table 4 Association of Extend of Burn with Albumin Level

\begin{tabular}{lccccc}
\hline & & \multicolumn{3}{c}{ Albumin } & \multirow{2}{*}{ p-value } \\
\cline { 2 - 5 } & & Hypoalbumin & Normal & Total & \\
\hline \multirow{2}{*}{ Extend of Burn } & $>25 \%$ & 19 & 0 & 19 & \multirow{2}{*}{$\mathbf{0 . 0 0 3}$} \\
\cline { 2 - 5 } & $<25 \%$ & 8 & 5 & 13 & \\
\hline Total & & $\mathbf{2 7}$ & $\mathbf{5}$ & $\mathbf{3 2}$
\end{tabular}

Based on table 4.4 , there were 19 patients with extend of burn for $>25 \%$, who were hypalbuminemia, while those with $<25 \%$ wounded area consisted of 8 patients with hypoalbuminemia and 5 patients with normal albumin levels. 
Based on table 4.4, there were 5 cells with expected value of less than 5, so the Fisher's Exact Test was used to analyze the variables. From the analysis utilizing Fisher's Exact Test $p=0.006$ $(p<0.05)$ was obtained, which meant that there is an association between the extend of burn with albumin level. This result is consistent with a previous research by Pérez-Guisado, et al. (2013). In this research, it was obtained that there is an association of the extend of burn with albumin level. This is possibly because burn injuries leads to loss of important proteins and acute inflammatory phase which affects the plasma protein synthesis in the liver. Larger total body surface area will cause lower serum albumin level due to higher burning level. The condition of low albumin levels in blood is called hypoalbuminemia. Hypoalbuminemia is often found in critically ill patients, particularly in burn injury patients. Even if the extend of the burn is less than $10 \%$ of body surface area, there will be changes in metabolism. Burn injuries results in hypermetabolic and hypercatabolic responds, depending on the extend and depth of the wound. The burn injury of more than $20 \%$ of body surface area will cause a huge loss of extracellular fluid, which in turn will trigger a shock by increasing blood vessel permeability and decreasing plasma albumin from the wound exudate. Hypoalbuminemia also results in complications related to the increase of extravascular fluid, including edema, disorder in healing proccess, and sepsis susceptibility.

\section{Conclusion}

Based on the data analysis and discussion which has been done in this research, a conclusion could be infered that there were 32 patients with burn injuries from 1 January 2017 to 31 December 2018 at Haji Adam Malik general hospital, predominated by 24 males. Based on the age of the patients, it was predominated by 23 people aged 20 to 40 years. According to the extend of the burns, the majority was 27 people with wounds of more than $25 \%$ body surface area. Based on albumin level, it was discovered that there were more patients with hypoalbuminemia, as many as 27 people, compared to those with normal levels. The analysis using Fisher's Exact Test yieled a result that there is an association between the extend of the burn with albumin level on patients with burn injuries at Haji Adam Malik general hospital 2017 to 2018.

\section{REFERENCES}

[1] Moenadjat, Y. 2009,Luka Bakar Masalah dan Tatalaksana. 4th edn., Balai Penerbit FKUI, Jakarta.

[2] Aghakhani, N. et al.2011, 'Prevalence burn injuries and risk factors in persons older the 15 years in Urmia burn center in Iran', Caspian Journal of Internal Medicine, 2(2), pp. 240244.

[3] WHO, 2018,Burns. Available at: https://www.who.int/news-room/fact-sheets/detail/burns (Accessed: 24 May 2019).

[4] Depkes, 2013, 'Riskesdas 2013', Jakarta: Badan Penelitian dan Pengembangan Kesehatan Departemen Kesehatan Republik Indonesia, (Penyakit Menular), p. 103. doi: 10.1007/s13398-014-0173-7.2.

[5] Tiwari, VK. 2012 . Burn Wound : How It Differs From Other Wounds. Indian Journal of Plastic Surgery Vol. 45, 364-373.

[6] Pérez-Guisado, J. et al.2013, 'Serum albumin levels in burn people are associated to the 
total body surface burned and the length of hospital stay but not to the initiation of the oral/enteral nutrition.', International journal of burns and trauma, 3(3), pp. 159-163. Available http://www.ncbi.nlm.nih.gov/pubmed/23875122\%0Ahttp://www.pubmedcentral.nih.gov/ar ticlerender.fcgi?artid=PMC3712404.

[7] Aguayo-Becerra, O. et al.2013, 'Serum albumin level as a risk factor for mortality in burn patients', Clinics, 68(7), pp. 940-945. doi: 10.6061/clinics/2013(07)09.

[8] Febrianto, R. (2016) 'Hubungan Luka Bakar Derajat Sedang dan Berat Menurut Kategori American Burn Association dan Faktor-Faktor yang Mempengaruhi Kejadian Sepsis di RSUP dr. Kariadi', Jurnal Kedokteran Diponegoro. Fakultas Kedokteran Universitas Diponegoro.

[9] Awan, S. A. et al. (2014) 'Manfaat Suplementasi Ekstrak Ikan Gabus Terhadap Kadar Albumin, MDA pada Luka Bakar Derajat II', JST Kesehatan. Fakultas Kedokteran Universitas Hasanuddin, 4(4), pp. 385-393. 